\title{
Sustainable collaboration: The impact of governance and institutions on sustainable performance
}

Eva Niesten ${ }^{a, *}$, Albert Jolink ${ }^{b}$, Ana Beatriz Lopes de Sousa Jabbour ${ }^{c}$, Maryse Chappin ${ }^{\mathrm{d}}$, and Rodrigo Lozano e,f

\author{
a Manchester Institute of Innovation Research, Alliance Manchester Business School, University of Manchester, \\ Manchester, United Kingdom \\ b Coventry University Business School, Coventry University, Coventry, United Kingdom \\ c Design Manufacture and Engineering Management, University of Strathclyde, Glasgow, United Kingdom \\ ${ }^{\mathrm{d}}$ Copernicus Institute of Sustainable Development, Utrecht University, Utrecht, The Netherlands \\ ${ }^{\mathrm{e}}$ Faculty of Engineering and Sustainable Development, University of Gävle, Gävle, Sweden \\ ${ }^{f}$ Organisational Sustainability, Ltd, 40 Machen Place, Cardiff, UK, CF11 6EQ
}

\begin{abstract}
Collaboration between firms is important to stimulate the transition to a more sustainable society. This special volume shows that collaboration is indeed one of the preferred forms of governance to manage relations between firms in a sustainability context. Collaboration enhances sustainable benefits by creating legitimacy of sustainable technologies, reducing waste and improving environmental and social performance of firms. The institutional environment, in particular environmental laws and regulations, has a beneficial impact on collaboration and relationship management in sustainable supply chains. Two studies in this special volume show, however, that stringent environmental regulations may hinder economic performance and result in outsourcing to foreign suppliers with potential detrimental effects for environmental performance. These negative effects can be overcome by firms that invest in sustainable innovation. This special volume also shows that ecoinnovation leads to sustainable benefits, such as lower greenhouse gas emissions.
\end{abstract}

Keywords: Sustainable collaboration; governance; institutions; economic performance; environmental performance

\section{Introduction}

Over the past decades firms have increased their efforts at adopting sustainable business practices (Sharma and Henriques, 2005). Firms have changed their product portfolios, production processes and supply chains in response to government regulations, demand from 
consumers and pressures from NGOs (Ählström and Sjöström, 2005; Hoejmose et al., 2012). In addition, firms proactively change their business processes when they experience that pursuing environmental and social goals can lead to cost reductions and enhance their competitive advantage (Carroll and Shabana, 2010); however, firms cannot address sustainability challenges on their own, joint efforts are needed to integrate environmental and social considerations into economic decisions (Seuring and Gold, 2013).

A large number of studies have shown that joint efforts are a key element of sustainability, and collaborative approaches can help build stronger and more sustainabilityoriented organisations (e.g., Lozano, 2007; 2008; Govindan et al., 2016). Firms pursue sustainability challenges in collaboration with consumers, governmental agencies, NGOs, universities and other firms to facilitate the transition to a more sustainable society (Seuring and Gold, 2013). Research on collaboration, aimed at improving environmental sustainability, has mainly focused on relations between firms and NGOs, and between firms and the government in so-called public-private partnerships (King, 2007; Delmas and Terlaak, 2001). Relatively few studies have addressed inter-firm environmental collaboration (Wassmer et al., 2014, p. 17).

Inter-firm collaboration is viewed as one of the three core governance structures that coordinate relations between firms (Williamson, 1996), next to markets and hierarchies (Coase, 1937; Williamson, 1998). When pursuing a sustainable opportunity, inter-firm collaboration is an important governance structure for several reasons. When firms sell sustainable products and services to end users, they need to consider sustainability in the entire supply chain and collaboration with supply chain partners is therefore required (Jolink and Niesten, 2015; Seuring and Müller, 2008). Furthermore, the adoption of sustainable technologies can be accelerated when they are implemented in different sectors, and crosssector collaboration between firms will therefore enable the diffusion of sustainable innovations (Van Tulder et al., 2016).

While some recent studies have begun to address inter-firm collaboration with a sustainability goal (e.g. Hoejmose et al., 2012), they have also highlighted that the complexity of governance and inter-firm relations in the context of sustainability will shape the research agenda for the next decade (Govindan et al., 2016). This special volume (SV) contributes to this research agenda by focusing on inter-firm collaborations that stimulate sustainable benefits. The articles in this SV analyse collaboration in a sustainability context from various theoretical perspectives, such as institutional theory and strategic management (see table 1). Section 2 of this introductory article will outline the core argument of these 
theories, and emphasize how they explain the need for inter-firm collaboration, the impact of institutions on collaboration, and the performance consequences of collaboration. Section 3 will summarize the key contributions of each article in this volume, highlighting the insights from institutional theory and strategic management to inter-firm environmental collaboration and its sustainable benefits. Section 4 concludes and offers suggestions for future research.

\section{Collaboration, institutions and performance: Insights from institutional theory and strategic management}

Institutional theory and strategic management offer a long research tradition in the area of inter-firm collaboration (Gray and Wood, 1991). Within these theoretical perspectives, transaction cost economics and the resource-based view have been identified as the leading theories that study governance decisions of firms (Ménard, 2005). These theoretical perspectives explain why firms prefer to collaborate (section 2.1), how institutions influence collaboration (section 2.2), and when a choice for collaboration as a governance form can enhance performance (section 2.3).

\subsection{Collaboration as a governance form}

The governance of inter-firm relations refers to the coordination or management of transactions between firms (Williamson, 1996). Governance is a "means by which order is accomplished in a relation in which potential conflict threatens to undo or upset opportunities to realize mutual gains" (Williamson, 1998, p. 37). The three focal forms of governance are markets, hierarchies and hybrids (Ménard, 2005). In markets, firms decide to exchange based on the price of products and services, whereas in hierarchies relations are managed by authority and command (Ménard, 2005). Hybrids or collaborative forms of governance are viewed as intermediate forms, located in between markets and hierarchies. They are defined as: "legally autonomous entities doing business together, mutually adjusting with little help from the price system, and sharing or exchanging technologies, capital, products, and services, but without a unified ownership" (Ménard, 2004, p. 348). Examples of collaborative governance forms are numerous, and include contractual alliances, joint R\&D alliances, marketing alliances, production alliances, unequal joint ventures, 50-50 joint ventures, associations and cooperatives (Jolink and Niesten, 2012; 2016; Kale and Singh, 2009).

The resource-based view of the firm argues that firms use collaborative governance forms to access knowledge, resources and technologies of other firms (Eveleens et al., 2016; Lavie, 2006). When a collaborative relation is characterized by the transfer of valuable 
knowledge and resources and by investments in specific assets, the relation may give rise to opportunistic behavior by the partners (Sampson, 2004). The core argument of transaction cost economics is that firms can make effective governance choices by matching a governance form to the hazard of opportunism associated with the inter-firm relation (Williamson, 1996). Several scholars have shown that firms prefer joint ventures over contractual alliances when there is a high potential for opportunistic behavior (Jolink and Niesten, 2016; Sampson, 2004).

\subsection{Influence of institutions on collaboration}

Within institutional theory, scholars have studied the impact of the institutional environment, or the "rules of the game", on collaboration between firms (Williamson, 1998; North, 1990). The rules of the game influence the formation, functioning and the value generation potential of collaboration (Jolink and Niesten 2012). For example, the legislation on the liberalization of industries has led to the formation of hybrid governance forms (Künneke, 2008; MacKenzie, 2008). The presence of the institutional environment affects governance choices, and additionally the failings of the institutional environment determine governance choices. Hence, collaborative governance structures may function as safeguards for inter-firm relations where the institutional environment does not provide safeguards (Jolink and Niesten, 2012). For example, firms collaborate in associations based on trust and power in the absence of strong legal institutions (Lyon, 2006); however, when the institutional environment does provide strong safeguards it allows firms and their alliances to create substantial value (Andersen et al., 2007).

\subsection{Collaboration and performance}

The importance of studying the governance of inter-firm relations lies in the positive influence of effective governance on the performance of firms and alliances (Sampson, 2004). Hoetker and Mellewigt (2009) found that formal and relational mechanisms can be used to coordinate resources in alliances, and that formal mechanisms are best suited to property-based assets whereas relational governance is best suited to knowledge-based assets. When firms choose an effective governance mechanism, this will have a positive impact on the achievement of certain alliance goals, such as access to capital, new markets, technical and marketing know-how, or reductions in costs and risk (Hoetker and Mellewigt, 2009). Other studies (e.g., Hoffmann and Schlosser, 2001) have shown a relation between effective 
governance choices and managerial assessments of alliance success, and a greater innovative performance of alliances as measured by citation-weighted patent counts (Sampson, 2004).

\section{Overview of the articles in this SV}

The twelve articles in this SV focus on the three themes discussed in section 2, and offer an application of these themes in institutional theory and strategic management to a sustainability context. Figure 1 offers a summary of the three themes. A first set of four articles focuses on the governance level, and studies collaboration between firms, and between firms and consumers (section 3.1). A second set of five articles addresses the impact of institutions, in particular environmental regulations, on collaboration. The articles also show how collaboration and institutions influence economic performance and especially environmental and social performance (section 3.2). A final set of three articles studies interfirm relations and environmental performance at an industry level (section 3.3). Table 1 provides a summary of the articles in this SV, with information on the theme, theory, method and empirical context of each article. The fourth column of the table provides information on the sustainability goals addressed in each article.

Figure 1. Institutions, collaboration and performance (adapted from Williamson, 1998)

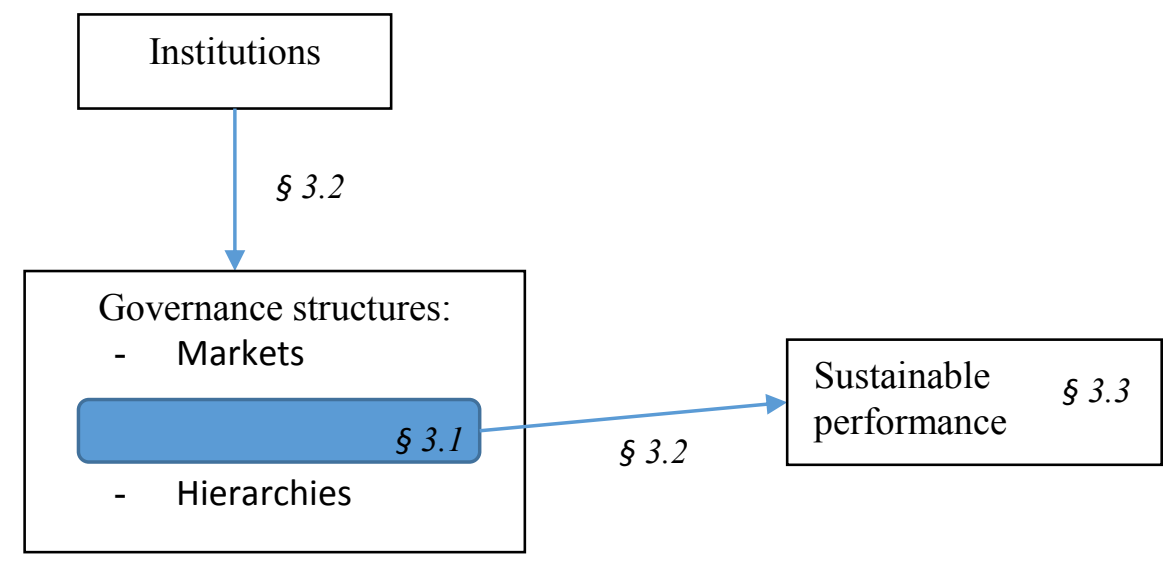

\subsection{Sustainable collaboration: Governance of inter-firm relations and firm-consumer relations}

The transition to a more sustainable world requires innovation as well as legitimation and active participation of all stakeholders. The article by Kishna et al. (in this volume) argues that the development of sustainable technologies needs to be accompanied by organizations promoting the legitimacy of the technologies. The article provides an account of how inter- 
firm collaboration in the bio-plastics industry is able to create legitimacy for sustainable technologies. In their study, the complementary resources of alliance partners, such as a sustainable technology, a large customer base and substantial production capacity, facilitate the desirability and appropriateness of a technology. The majority of the alliances in this study are inter-firm alliances, but a small subset involves alliances between firms, governments, universities, research institutes, and NGOs. The main outcome of Kishna et al. (in this volume) is that alliances among this diverse set of stakeholders take place at a precompetitive stage and act as institutional entrepreneurs to set the conditions for the transition.

The emphasis on collaboration resurfaces in Fischer and Pascucci (in this volume), who elaborate on new organizational forms of inter-firm collaborations that are required for a transition to a more sustainable society. Fisher and Pascucci argue that there are multiple roads to a sustainable transition, identifying fixed supply chains with technical improvements but also entirely new compositions of supply chains. Using empirical evidence of the Dutch textile industry, they make a persuasive case of how chain coordination, contracting and financial mechanisms are key organizational elements that facilitate a sustainable transition. The authors conclude that the benefits of collaborative efforts may go beyond the performance of the inter-firm collaboration, resulting in bottom-up effects on the formal rules at the level of the institutional environment.

Two articles in this SV show that sustainable collaboration involves business-tobusiness and business-to-consumer relations (Aschemann-Witzel et al.; Zhu et al.). In their study on food waste, Aschemann-Witzel et al. (in this volume) present new governance forms of supply chains, where the involvement of consumers is instrumental. They identify different initiatives aimed at reducing food waste, such as supplying information on how to reduce waste, redistributing food and promoting changes in the supply chain. The article concludes that supply chain collaboration is still one of the pivotal features for the success of the reduction of food waste, as are the competencies of the supply chain partners, but the timing of the process is crucial to involve the consumers.

Zhu et al. (in this volume) elaborate on this role of consumers by studying two greening practices of supply chains: green purchasing and green innovation. The article discusses that greening supply chains through green purchasing is not affected by informal consumer involvement and require formal consumer contracts. Greening supply chains through green innovation is positively influenced by active consumer cooperation and reciprocity, but negatively influenced by passive consumer trust. The article highlights that it is important to consider different types of structures to govern the relation between firms and 
consumers (e.g. contracts versus relational governance), because they have different effects on environmental performance.

\subsection{Impact of institutions on collaboration: Environmental, social and economic} performance implications

Zeng et al. (in this volume) find that institutional pressures, which are embedded in environmental laws and regulations, are pivotal means for developing supply chain relationship management in Chinese eco-industrial parks. The article shows that sustainable supply chain practices are an important antecedent to pursue circular economy principles in eco-industrial parks. Based on these findings, the authors propose that organisations in ecoindustrial parks should consider environmental laws and regulations to develop and manage supply chain relationships and, as a consequence, improve the circular economy capability in the context of eco-industrial park firms.

Esfahbodi et al. (in this volume) underpin the beneficial role played by the exogenous pressures of governments, which drive organisations to pursue sustainable supply chain management (SSCM) practices. The article presents the relationships between institutional pressures, SSCM practices and environmental and economic performance. The findings are based on a survey with chemical, electronic, automotive and mechanical engineering sectors, which are considered polluters and resource consumption sectors in the United Kingdom. The article highlights that SSCM practices can influence economic performance, and that exogenous pressures of governments can therefore be considered an antecedent of the results.

According to Ramanathan et al. (in this volume), the inflexibility of environmental regulations, which prescribe specific processes or products for achieving a particular outcome, can actually hinder economic performance. The research suggests that companies can be in a position to reverse this hindrance by transforming resources and capabilities into innovation. The findings of this article are based on case studies of companies located in China and in the United Kingdom.

Husted and Sousa-Filho (in this volume) analyse whether institutional conditions such as stakeholder country orientation and country risk, can moderate the relationship between sustainability governance and environmental, social and governance (ESG) performance. Sustainability governance refers to the governance of relations between firms aimed at sustainability. The article uses secondary data from the Sustainalytics and Bloomberg ESG databases and the sample consisted of 459 firms from nine countries. High stakeholder 
country orientation and low country risk tend to facilitate the implementation of in-house, outsourced and collaborative sustainability governance initiatives and, as a consequence, increase ESG performance. The article shows that collaborative governance produces the greatest ESG performance.

Antonietti et al. (in this volume) contribute to the theme of institutional pressures by researching the impact of environmental policy on firms' governance decisions, including the decision whether to outsource or start a foreign direct investment. In the context of Italian companies, the article shows that a stricter environmental regulation is related to a higher probability of production being outsourced to international suppliers. The authors also conclude that eco-innovative firms are more likely to adopt governance decisions that enable a stricter control over the supply chain, as is the case for foreign direct investments.

\subsection{Environmental benefits of eco-innovation at the industry level}

Wesseling and van der Vooren (in this volume) focus on the diffusion of clean technologies in a mature energy-intensive industry. By means of a structural-functional approach they identify interdependent systemic problems that hinder the sustainability transformation of the Dutch concrete industry. They show that the mature nature of this industry results in strategic behavior of firms in the supply chain, protecting their vested interests. The vested interests of these firms are not necessarily in line with the public interest of a more sustainable sector. The article provides an ordered set of policy recommendations focused, first, on mitigating the power of the vested interests, second, on facilitating buyersupplier knowledge diffusion, and finally, on supporting market creation for clean technologies in the concrete industry.

Li et al. (in this volume) address the collection of waste electrical and electronic equipment in China by comparing informal collection channels with formal ones. The article analyzes this dual-channel collection supply chain using a Stackelberg game model based on different channel preferences of consumers and the economic value of waste. It shows that both the government and formal waste collectors implement governance mechanisms to control or utilize the informal collection channel. The benefits for the government are an improvement of societal welfare and a reduction in environmental pollution, whereas for the formal collector the benefits lie in strengthening its competitive position and realizing mutual gains. 
Crespi et al. (in this volume) analyze direct and indirect effects of eco-innovation to explain the environmental performance of industries (in terms of a reduction of total greenhouse gas, $\mathrm{CO}_{2}, \mathrm{NOx}$, and $\mathrm{SOx}$ emissions). The article conducts a large quantitative study of 14 manufacturing industries in 27 EU-countries for the time period 1995-2007. The results show that for all emission types there is a strong positive direct effect of ecoinnovation on the environmental performance of industries. They also show that there are indirect effects, such as inter-industry effects of eco-innovation via market transactions. Ecoinnovations that are being developed upstream, both domestically and internationally, have positive effects on the total industry's environmental performance. Finally, the study demonstrates the possible benefits of the diffusion of green technologies in the supply chain.

\section{Conclusions}

This SV makes three contributions to the study of inter-firm environmental collaboration. First, it studies effective governance of inter-firm relations in a sustainability context by applying insights from institutional theory and strategic management. Markets, hierarchies and collaboration are generally considered to be the three main governance forms. This SV highlights that in a sustainability context, collaborative governance forms are often necessary to achieve sustainable benefits, such as creating legitimacy of sustainable technologies (Kishna et al., in this volume), reducing food waste (Aschemann-Witzel et al., in this volume), and improving environmental, social and governance performance (Husted and Sousa-Filho, in this volume). Several studies offer detailed insights into what is required to make collaborative governance a success. For instance, Fischer and Pascucci (in this volume) underpin the importance of effective governance by arguing that firms need to pay attention to chain coordination, contracting and financial mechanisms to facilitate a sustainable transition. Zhu et al. (in this volume) show that firms prefer relational governance over contracts in their governance of firm-consumer relations under certain conditions.

Second, the SV analyses the impact of institutions on collaborative governance and performance. Several studies in this SV show that institutions, and in particular environmental laws and regulations, have a positive impact on managing relations between firms in sustainable supply chains, and lead to a greater environmental and economic performance (Zeng et al., in this volume; Esfahbodi et al., in this volume). Other beneficial institutional conditions, such as a low country risk, allow collaboration to create an improved environmental, social and governance performance (Husted and Sousa-Filho, in this volume). These findings are in line with institutional theory where institutional environments provide 
safeguards to allow firms and alliances to create substantial value (e.g., Andersen et al., 2007).

Third, the SV shows that collaboration and institutions have a beneficial impact on environmental, social and economic performance (e.g. Zhu et al., in this volume; Esfahbodi et al., in this volume; $\mathrm{Li}$ et al., in this volume). Earlier research on alliances has predominantly focused on private benefits, but has more or less neglected the public benefits (Niesten and Jolink, 2015). This SV thus extends beyond institutional theory's and strategic management's focus on the financial performance of firms, and offers evidence on improved sustainable benefits.

\subsection{Future research directions}

This SV has provides evidence on collaboration, governance and institutions in different sustainability contexts, but more research is required on how the resources and transactions in sustainable supply chains differ from resources and transactions in traditional supply chains. This will enable a better understanding of why some forms of governance are more effective for sustainability transactions, and will thus improve performance. If the transaction or resource attributes are different in a sustainability context, the governance consequences of these differences will need to be addressed. An article in this SV has addressed this research agenda by arguing that "sustainability problems, by their nature, are complex and different from the products and services with which firms typically deal... this complexity needs to be matched by more complex forms of governance that draw upon resources and capabilities that may lie outside the boundaries of the firm" (Husted and Sousa-Filho, in this volume, p. 9). This future research may find that traditional explanations will prove to be unsatisfactory and require extensions to explain governance and collaboration in a sustainability context.

\section{Acknowledgments}

The SV team wishes to thank all the authors who submitted articles for this SV and the reviewers who reviewed manuscripts in a timely manner. A special thanks to Professor Donald Huisingh and the editorial advisory board for their support in developing the call for articles of this SV.

\section{References}

- Ählström, J., \& Sjöström, E. 2005. CSOs and business partnerships: Strategies for interaction. Business Strategy and the Environment, 14, 230-240. 
- Andersen, B., Kozul-Wright, R., \& Kozul-Wright, Z. 2007. Rents, rights n'rhythm: Cooperation, conflict and capabilities in the music industry. Industry and Innovation, 14, 513-540.

- Antonietti, R., De Marchi, V., and Di Maria, E. 2017. Governing offshoring in a stringent environmental policy setting: evidence from Italian manufacturing firms

- Aschemann-Witzel, J., de Hooge, I., Rohm, H., Normann, A., Bonzanini Bossle, M., Grønhøj, A. and Oostindjer, M. 2017. Key characteristics and success factors of supply chain initiatives tackling consumer-related food waste - a multiple case study.

- Carroll, A.B., and Shabana, K.M. 2010. The business case for corporate social responsibility: A review of concepts, research and practice. International Journal of Management Reviews, 12: 85-105.

- Costantini, V., Crespi, F., Marin, G., and Paglialunga, E. 2017. Eco-innovation, sustainable supply chains and environmental performance in European industries. Journal of Cleaner Production, in press.

- Delmas, M. A., and Terlaak, A. 2001. A framework for analyzing environmental voluntary agreements. California Management Review, 43, 44-63.

- Esfahbodi, A., Zhang, Y., Watson, G. and Zhang, T. 2017. Governance pressures and performance outcomes of sustainable supply chain management - An empirical analysis of UK manufacturing industry. Journal of Cleaner Production, in press.

- Eveleens, C., van Rijnsoever, F., and Niesten, E. (2016). How network-based incubation helps startup performance: a systematic review against the background of management theories. Journal of Technology Transfer. DOI: 10.1007/s10961-016-9510-7.

- Fischer, A and Pascucci, S. 2017. Institutional incentives in Circular Economy transition: the case of material use in the Dutch Textile Industry.

- Govindan, K., Seuring, S., Zhu, Q., Garrido Azevedo, S. Accelerating the transition towards sustainability dynamics into supply chain relationship management and governance structures. Journal of Cleaner Production, 112, 1813-1823.

- Gray, B. and Wood, D. 1991. Collaborative alliances: Moving from theory to practice. Journal of Applied Behavioral Science, 27, 3-22.

- Hennart, J-F. 1991. The transaction cost theory of joint ventures: An empirical study of Japanese subsidiaries in the United States. Management Science, 37: 483-497.

- Hoejmose, S., Brammer, S., Millington, A. 2012. "Green" supply chain management: The role of trust and top management in B2B and B2C markets. Industrial Marketing Management, 41, 609-620.

- Hoetker G, Mellewigt T. 2009. Choice and performance of governance mechanisms:

Matching alliance governance to asset type. Strategic Management Journal, 30(10): 1025-

1044.

- Hoffmann WH, Schlosser R. 2001. Success factors of strategic alliances in small and medium-sized enterprises - An empirical survey. Long Range Planning, 34(3): 357-381.

- Husted, B. and de Sousa-Filho, J. 2017. The impact of sustainability governance, country stakeholder orientation, and country risk on environmental, social, and governance performance. Journal of Cleaner Production, in press.

- Jolink, A., and Niesten, E. 2012. Recent qualitative advances on hybrid organizations: Taking stock, looking ahead. Scandinavian Journal of Management, 28(2), 1149-1161.

- Jolink, A., and Niesten, E. 2016. The impact of venture capital on governance decisions in collaborations with start-ups. Small Business Economics, 47(2), 331-344.

- Kale, P. and Singh, H. 2009. Managing strategic alliances: what do we know now, and where do we go from here? Academy of Management Perspectives, 23, pp. 45-62.

- King, A. 2007. Cooperation between corporations and environmental groups: A transaction cost perspective. Academy of Management Review, 32, 889-900.

- Kishna, M., Niesten, E., Negro, S., and Hekkert, M. 2017. The role of alliances in creating legitimacy of sustainable technologies: A study on the field of bio-plastics. Journal of Cleaner Production, in press.

- Künneke, R. 2008. Institutional reform and technological practice: The case of electricity. Industrial and Corporate Change, 17, 233-265.

- Lavie, D. 2006. The competitive advantage of interconnected firms: An extension of the resourcebased view. Academy of Management Review, 31(3), 638-658. 
- Li, Y., Xu, F. and Zhao, X. 2017. Governance mechanisms of dual-channel reverse supply chains with informal collection channel. Journal of Cleaner Production, in press.

- Lozano, R. 2007. Collaboration as a pathway for sustainability. Sustainable Development, 15, 370381.

- Lozano, R. 2008. Developing collaborative and sustainable organisations. Journal of Cleaner Production, 16, 499-509.

- Lyon, F. 2006. Managing co-operation: Trust and power in Ghanaian associations. Organization Studies, 27, 31-52.

- MacKenzie, R. 2008. From networks to hierarchies: The construction of a subcontracting regime in the Irish telecommunications industry. Organization Studies, 29(6), 867-886.

- Ménard, C. 2004. The economics of hybrid organizations. Journal of Institutional and Theoretical Economics, 160, 345-376.

- Ménard, C. 2005. Chapter 12: A New Institutional Approach to Organization. In: Ménard, C. and Shirley, M. 2005. Handbook of New Institutional Economics. Dordrecht: Springer.

- Niesten, E., and Lozano, R. 2015. Making, buying and collaborating for more sustainable production and consumption. Journal of Cleaner Production, 100, 1-3.

- Niesten, E., and Jolink, A. 2015. The impact of alliance management capabilities on alliance attributes and performance: A literature review. International Journal of Management Reviews, 17(1), 69-100.

- North, D. 1990. Institutions, institutional change and economic performance. Cambridge:

Cambridge University Press.

- Oxley, J. 1999. Institutional environment and the mechanisms of governance: the impact of intellectual property protection on the structure of inter-firm alliances. Journal of Economic Behavior \& Organization, 38: 283-309.

- Ramanathan, R., He, Q., Black, A., Ghobadian, A. and Gallear, D. 2017. Environmental regulations, innovation and firm performance: A revisit of the Porter hypothesis. Journal of Cleaner Production, in press.

- Sampson, R. 2004. The costs of misaligned governance in R\&D alliances. Journal of Law, Economics \& Organization, 20(2), 484-526.

- Seuring, S. and Müller, M. 2008. From a literature review to a conceptual framework for sustainable supply chain management. Journal of Cleaner Production, 16, 1699-1710.

- Seuring, S. and Gold, S. 2013. Sustainability management beyond corporate boundaries. Journal of Cleaner Production, 56, 1-200.

- Sharma, A. and Henriques, I. 2005. Stakeholder influences on sustainability practices in the

Canadian forest products industry. Strategic Management Journal, 26, 159-180.

- Van Tulder, R., Crane, A., Seitanidi, M. and S. Brammer. 2016. Enhancing the impact of cross-

sector partnerships: Four impact loops for channelling partnership studies. Journal of Business Ethics, $135,1-17$.

- Wassmer, U., Paquin, R., Sharma, S. 2014. The engagement of firms in environmental collaborations: Existing contributions and future directions. Business and Society, 53 (6), 754-786.

- Wesseling, J. and Van der Vooren, A. 2017. Lock-in of mature innovation systems: the transformation toward clean concrete in the Netherlands. Journal of Cleaner Production, in press.

- Williamson, O. 1996. The Mechanisms of Governance. Oxford University Press, New York.

- Williamson, O. 1998. Transaction cost economics: how it works; where it is headed. De

Economist, 146(1), 23-58.

- Zeng, H., Chen, X., Xiao, X., and Zhou, Z. 2017. Institutional pressures, sustainable supply chain management, and circular economy capability: Empirical evidence from Chinese eco-industrial park firms. Journal of Cleaner Production, in press.

- Zhu, Q., Feng, Y., and Choi, S-B. 2017. The role of customer relational governance in environmental and economic performance improvement through green supply chain management. Journal of Cleaner Production, in press. 
Table 1. Summary of articles in this SV

\begin{tabular}{|c|c|c|c|c|c|}
\hline Authors & Theme & Theory & Sustainability goals & Method & Empirical Context \\
\hline Kishna et al. & Inter-firm collaboration and legitimacy & $\begin{array}{l}\text { Institutional theory } \& \\
\text { strategic management }\end{array}$ & $\begin{array}{l}\text { Create legitimacy of sustainable } \\
\text { technologies }\end{array}$ & $\begin{array}{l}\text { Quantitative / } \\
\text { secondary data }\end{array}$ & Bio-plastics \\
\hline Fischer \& Pascucci & $\begin{array}{l}\text { New governance forms of inter-firm } \\
\text { relations }\end{array}$ & $\begin{array}{l}\text { Institutional theory / NIE \& } \\
\text { TCE literature }\end{array}$ & $\begin{array}{l}\text { Implement circular economy (CE) } \\
\text { principles }\end{array}$ & Case studies & Dutch textile industry \\
\hline $\begin{array}{l}\text { Aschemann-Witzel } \\
\text { et al. }\end{array}$ & $\begin{array}{l}\text { Governance of inter-firm collaboration } \\
\text { and } \mathrm{B} 2 \mathrm{C} \text { relations }\end{array}$ & $\begin{array}{l}\text { Management \& consumer } \\
\text { behaviour theory }\end{array}$ & $\begin{array}{l}\text { Reduce consumer-related food } \\
\text { waste }\end{array}$ & Case studies & Food waste \\
\hline Zhu et al. & $\begin{array}{l}\text { Formal and relational governance of } \\
\mathrm{B} 2 \mathrm{C} \text { relations }\end{array}$ & Strategic management & $\begin{array}{l}\text { Achieve environmental and } \\
\text { economic performance }\end{array}$ & $\begin{array}{l}\text { Quantitative } \\
\text { survey data }\end{array}$ & $\begin{array}{l}\text { Green purchasing \& innovation } \\
\text { in Chinese export city }\end{array}$ \\
\hline Zeng et al. & $\begin{array}{l}\text { Institutional pressures on sustainable } \\
\text { supply chain management (SSCM) and } \\
\text { impact on CE capability }\end{array}$ & $\begin{array}{l}\text { Institutional theory } \\
\text { capabilities view }\end{array}$ & $\begin{array}{l}\text { Integrate CE in supply chain } \\
\text { management }\end{array}$ & $\begin{array}{l}\text { Quantitative } \\
\text { survey data }\end{array}$ & $\begin{array}{l}\text { Chinese firms in eco-industrial } \\
\text { parks }\end{array}$ \\
\hline Esfahbodi et al. & $\begin{array}{l}\text { Institutional pressures on SSCM and } \\
\text { performance consequences }\end{array}$ & Institutional theory & $\begin{array}{l}\text { Implement SSCM to enhance } \\
\text { environmental performance }\end{array}$ & $\begin{array}{l}\text { Quantitative / } \\
\text { survey data }\end{array}$ & UK manufacturing industry \\
\hline Ramanathan et al. & $\begin{array}{l}\text { Firms' response to regulation and impact } \\
\text { on environmental and economic } \\
\text { performance }\end{array}$ & $\begin{array}{l}\text { Strategic management / } \\
\text { resources/capabilities view }\end{array}$ & $\begin{array}{l}\text { Achieve environmental and } \\
\text { economic performance }\end{array}$ & Case studies & $\begin{array}{l}\text { UK \& Chinese manufacturing, } \\
\text { oil, electric, telecom \& } \\
\text { pharmaceutical firms }\end{array}$ \\
\hline $\begin{array}{l}\text { Husted \& Milton } \\
\text { de Sousa-Filho }\end{array}$ & $\begin{array}{l}\text { Impact of governance on performance } \\
\text { and role of institutions }\end{array}$ & $\begin{array}{l}\text { Institutional theory \& } \\
\text { strategic management/RBV }\end{array}$ & $\begin{array}{l}\text { Achieve environmental, social and } \\
\text { governance performance }\end{array}$ & $\begin{array}{l}\text { Quantitative / } \\
\text { secondary data }\end{array}$ & $\begin{array}{l}\text { Firms in Sustainalytics database } \\
\text { in } 9 \text { countries }\end{array}$ \\
\hline Antonietti et al. & $\begin{array}{l}\text { Relation between environmental } \\
\text { regulatory stringency and governance }\end{array}$ & $\begin{array}{l}\text { Institutional theory / refers } \\
\text { to TCE \& RBV }\end{array}$ & $\begin{array}{l}\text { Address environmental impacts of } \\
\text { international production }\end{array}$ & $\begin{array}{l}\text { Quantitative / } \\
\text { secondary data }\end{array}$ & Italian manufacturing industry \\
\hline $\begin{array}{l}\text { Wesseling \& Van } \\
\text { der Vooren }\end{array}$ & $\begin{array}{l}\text { Interdependent systemic problems and } \\
\text { lock-in in innovation systems }\end{array}$ & $\begin{array}{l}\text { Technological innovation } \\
\text { systems }\end{array}$ & Adopt sustainable technology & \begin{tabular}{l|} 
Qualitative / \\
interview data
\end{tabular} & $\begin{array}{l}\text { Clean concrete in the } \\
\text { Netherlands }\end{array}$ \\
\hline Li et al. & $\begin{array}{l}\text { Effectiveness of three forms of } \\
\text { governance of collection channels }\end{array}$ & Supply chain management & $\begin{array}{lll}\begin{array}{l}\text { Improve } \\
\text { collection }\end{array} & \text { end-of-life product } \\
\end{array}$ & $\begin{array}{l}\text { Stackelberg } \\
\text { game model }\end{array}$ & $\begin{array}{l}\text { Waste electrical and electronic } \\
\text { equipment in China }\end{array}$ \\
\hline Crespi et al. & $\begin{array}{l}\text { Impact of green innovation on } \\
\text { environmental performance in sector and } \\
\text { across sectors }\end{array}$ & Environmental economics & Reduce greenhouse gas emissions & $\begin{array}{l}\text { Quantitative / } \\
\text { secondary data }\end{array}$ & $\begin{array}{lr}\text { Environmental } & \text { technologies in } \\
\text { European } & \text { manufacturing } \\
\text { industries } & \\
\end{array}$ \\
\hline
\end{tabular}

